\title{
The Analysis of the Coherence of the Change in the Financial Situation
}

\author{
Jana Kliestikova $^{\mathrm{a} *}$, Maria Kovacova ${ }^{\mathrm{b}}$, Pavol Kubala ${ }^{\mathrm{c}}$ \\ Faculty of Operation and Economics of Transport and \\ Communications \\ University of Zilina \\ Zilina, the Slovak Republic \\ a*jana.klestikova@fpedas.uniza.sk \\ b maria.kovacova@fpedas.uniza.sk \\ ckubala.pavol@dpb.sk
}

\author{
Andrea Drugau-Constantin \\ Faculty of Administration and Public Management \\ Bucharest University of Economic Studies \\ Bucharest, Romania \\ andreeadrugau@gmail.com
}

\begin{abstract}
Nowadays, businesses face many challenges. Changes in the economy are not one-off; change of state of the company from going bankrupt to financially healthy and vice versa is a gradual process. This process is dynamic and influenced by many macroeconomic and microeconomic factors. Therefore, the knowledge of the overall process of changing in the financial situation has a crucial influence on corporate decision-making. The paper focuses on the description of different forms of financial distress as well as the analysis and description of corporate failure as an integral, continuous process in three dimensions.
\end{abstract}

Keywords-Bussiness failure; Financial health; Corporate finance; Bankruptcy

\section{INTRODUCTION}

Today at the time of global economy and economic networks the emergence and disappearance of businesses happens much more often than it used to be in the past. Due to the globalization and interdependence of individual national economies, companies' failures and bankruptcies are more pronounced in quantitative terms (especially in terms of volume of assets) [1]. The individual national economies do not work separately but in a very intense interaction, which means that the economies of individual countries are increasingly dependent on each other so the financial crisis in one country will be with a short delay transferred to the next country and may soon become global $[2,3]$. An example may be the recent financial and economic crisis, which has spread quite rapidly from the US to the rest of the world and has reached global dimension and character.

The interdependence of national economies and individual companies points to the need to perceive change in the financial situation of enterprises as a dynamic process. Business bankruptcy is not a one-time case, but it is a gradual process consisting of several phases [4]. The paper focuses on the description of different forms of financial distress as well as the analysis and description of corporate failure as an integral, continuous process in three dimensions.

\section{BUSSINESS FAILURE PROCESS}

In solving the problem of predicting financial health of a company, we may encounter some ambiguities in terminology. This situation is caused, on one hand, by a dual often dichotomical and antagonistic view on the problems (the economical or entrepreneurial view on the problem versus the purely legal view) and, on the other hand, by interpretation from the Anglo-Saxon scientific literature in which the meaning of technical terms partially overlaps [5]. Moreover, the view on definitions expressed by various authors is "far from" exactness.

Therefore, we would like to define the terms in way they are understood by the authors of this paper. However, we note that, as far as the terminology itself, the authors could be more or less unconcerned about it, because it is not a major issue to be addressed in the paper.

Failure means that the rate of return on capital invested, taking into account the risk, is significantly and consistently lower than the rates for similar investments. Mildly different criteria may also be used, including insufficient revenue to cover costs and average return on investment rates below the weighted average cost of capital. An enterprise may be in default for several years without failing to pay its current liabilities due to the absence of legally collectible debts.

Insolvency is a term that is used in the technical sense of this word. It indicates a lack of liquidity that occurs if an enterprise cannot meet its financial obligations. Technical insolvency is the most common cause of an official bankruptcy declaration. Bankruptcy comes when the insolvency of a company becomes critical, i.e. when the company's total liabilities exceed the market value of its total assets.

Default is another term that is related to financial difficulties of a company. The company will not go into bankruptcy immediately after default on making obligatory payments or paying interest. However, if an enterprise misses the payment of interest or principal repayments in government bonds and this is not repaired within 30 days, bankruptcy occurs. Over the last few decades, this type of debt has become a regular event. 
The last term is bankruptcy. An enterprise may go bankrupt when its total liabilities exceed the fair value of its total assets. On the other hand, the company may declare bankruptcy in respect of the applicable legislation of the country where it operates. The competent authority may then declare the company's bankruptcy or propose a recovery program for it. If the value of the company is higher than its individual stages, each of which has specific attributes and due to this fact contributes to the failure of the company each in different way [6, 7]. Financial hardship changes over time, which means that if a company once experiences it, it does not remain in the same state until company's demise or total recovery. Changes in the financial situation affect company's transition from one level of financial distress to another [8]. If the financial situation deteriorates, the company will most likely faces bankruptcy; but if the performance of the business improves, it has a chance to overcome its financial difficulties and re-establish its activity [9]. liquidation value, the company must participate in the recovery program.

As a tool for describing and understanding the significance of individual terms, we can mention the dynamic nature of the financial difficulties in which it is assumed that in transitioning to and from financial problems an enterprise goes through

For this reason the analysis of the coherence of the change in the financial situation with regard to the company status should use the three main dimensions of the financial distress, i. e. it should be understood as a three-dimensional process (Fig. 1.):

1. activities during a given period of time - the time frame,

2. impacts of different types of financial distress financial statuses,

3. characteristic features of performance at different levels of financial distress - phases of the process.
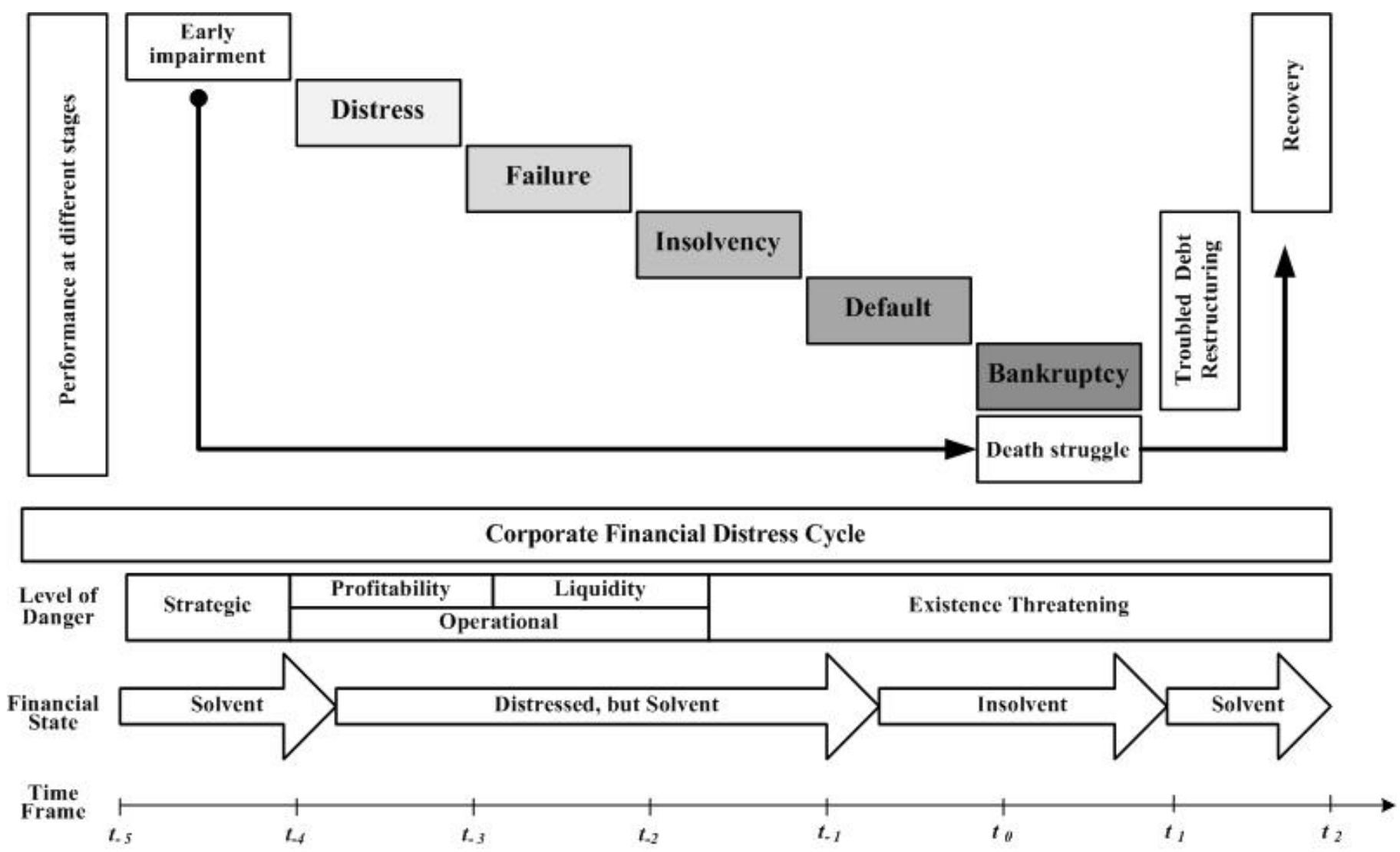

Fig. 1. Bussiness failure as an integral continuous process. 
The time frame covers the period from the first signs of a slight deterioration in the company's performance through an accelerated loss of its value to a full demise of the firm and then sometimes a subsequent recovery. This is the so-called cycle of financial distress. Determining the average length of the failure process is complicated due to difficulties in quantifying and identifying the first symptoms of financial stress or otherwise impairment of the company's financial health. Prediction models are not able to predict bankruptcy more than three years in advance [10]. Predicting failure more than three years in advance before the bankruptcy declaration significantly reduces the accuracy of predictive models [11]. An ex post financial stress analysis shows that the first observations are not significant, signs of deterioration in the financial health of a company occur five to six years before the bankruptcy itself. The existence of earlier signs of decline in company's performance is controversial. Although they exist, they are hard to observe, very slight, mostly strategic and not financial in nature so it is very difficult to measure them. Financial theory usually ignores these factors because of their low significance. The unfavorable development usually becomes observable about one to two years before the failure, when the company gets into a critical financial hardship [12]. It takes an average of two to three years after the failure until the company's debt is restructured and the company attains the level of performance that it had before the financial distress [13].

Financial statuses represent the second dimension of the business failure process. The collapse of a business with bad financial health usually occurs due to a change in liquidity. However, the reduction of liquidity resources does not necessarily have a negative impact on the level of company solvency. Usually in the early stages of financial distress the company continues to be solvent making it difficult to recognize the existence of negative processes within this company. Studies show that a further decline in liquidity causes the transition to other problems, but the level of company solvency may be revealed by analysing changes in cash flow compared to total assets [8]. The deepening of financial distress causes the illiquidity of corporate assets; and the value of the enterprise falls below a generally acceptable margin [14].

In this case the financial situation of the company is no longer sustainable and the company becomes unstable. As the financial distress of a company does not necessarily lead to a failure, even during that period this company may remain solvent, which means that its financial situation can be improved with a non-zero probability before the debt payment due date [15]. This state of distress with still continuing solvency of the company has different characteristics than the state of complete solvency. The decline in value highlights the growing role of financial leverage in detecting possible transformation of this business into an insolvent business. The change of the financial status to the insolvent one begins at the debt payment due date when the company is unable to repay its debt. The legal consequence of this is bankruptcy. Transformation or return to solvency is only possible after the successful completion of debt restructuring.
The last dimension of the integrated view on business failure is the phases of the business failure process. As Sherrer [16] states, there are different phases of decline, and warning signals vary according to specific stage. Occasionally not all symptoms occur; but on the other hand, there are good reasons to worry if they do occur [17].

Business financial health prediction models at early stages of their development (early sixties of the last century) were mainly used in academic circles and their use by wider professional circles came with a certain time delay. However, at present they constitute the immanent part of any funded financial analysis, not only for academic purpose, but also one for business practice as a basis for further detailed analyses or as information base for further funded decisions in the commercial sector. They are used as a source of information by:

- business management,

- owners or shareholders,

- research and pedagogical staff,

- investors,

- creditors,

- bank

- government authorities,

- financial advisers and analysts,

- auditors,

- business partners (suppliers, subscribers and customers),

- financial and market analysts,

- etc.

\section{CONCLUSION}

The financial distress of a business is not static, but a dynamic and it changes as a result of the impact of macroeconomic and corporate factors. Each of the stages of financial failure has specific causes and features that distinguish it from others $[18,19]$. In terms of time, the first signs of deterioration in financial health are observable already in the five to six years before the final phase, bankruptcy. However, these symptoms are not usually quantifiable and detectable by prediction models.

In another aspect of the process of business failure, it is necessary to examine the financial status of the company. Solvency of the company depends on the liquidity and persistently low liquidity can cause instability and insolvency. Finally, both these dimensions characterize the phases of the corporate failure process. From a comprehensive point of view, each phases of future corporate failure have their own time frame and characteristic financial statuses that indicates the future financial situation of the company. Knowing these characteristics makes it possible to use appropriate countermeasures to prevent business bankruptcy.

Overall, it should be noted that the future development of an analysis of corporate financial health should provide a 
response to the question of how to detect future failures in early stages of deterioration in financial health; which financial status is actually unfavorable to the enterprise and what measures should be applied.

\section{ACKNOWLEDGMENT}

The paper is an output of the science project VEGA 1/0428/17 Creation of new paradigms of financial management at the threshold of the 21 st century in conditions of the Slovak Republic.

\section{REFERENCES}

[1] T. Kliestik, M. Misankova, K. Valaskova, and L. Svabova, "Bankruptcy prevention: new effort to reflect on legal and social changes," Science and Engineering Ethics, vol. 24(2), pp. 791-803, 2018.

[2] G. A. Khmeleva, N.M. Tyukavkin, L.K. Agaeva, E.A. Kurnosova, and S. V. Sviridova, "How industry reacts to shocks: case out of Russian cities," Ekonomicko-manazerske spektrum, vol. 11(1), pp. 74-86, 2017.

[3] L. Kozubikova, L. Homolka, and D. Kristalas, "The Effect of Business Environment and Entrepreneurs' Gender on Perception of Financial Risk in The Smes Sector," Journal of competitiveness, vol. 9(1), pp.3650, 2017.

[4] A. P. Balcerzak, T. Kliestik, D. Streimikiene, and L. Smrcka, "NonParametric Approach to Measuring the Efficiency of Banking Sectors in European Union Countries," Acta Polytechnica Hungarica, vol. 14(7), pp. 51-70, 2017.

[5] J. Olah, Z. Zeman, I. Balogh, and J. Popp, "Future challenges and areas of development for supply chain management," Logforum, vol.14(1), pp. 127-138, 2018.

[6] J. Cygler and W. Sroka, "Coopetition Disadvantages: the Case of the High Tech Companies,” Inzinerine Ekonomika-Engineering Economics, vol. 28(5), pp. 494-504, 2017.

[7] M. Leber, A. Ivanisevic, J. Borocki, M. Radisic, and B. Slusarczyk, "Fostering Alliances with Customers for the Sustainable Product
Creation," Sustainability, vol. 10(9), 2018, available at: https:/www.mdpi.com/2071-1050/10/9/3204.

[8] N. Hill and S. Perry, "Evaluating Firms in Financial Distress: An Event History Analysis," Journal of Applied Business Research, vol. 12(3), pp. 60-71, 1996.

[9] G. H. Popescu and K. Creager, "Participatory forms of digital governance and peoplepowered services," Ekonomicko-manazerske spektrum, vol. 11(2), pp. 45-52, 2017.

[10] H. Platt and M. Platt, "Predicting Corporate Financial Distress: Reflections on Choice-Based Sample Bias," Journal of Economics and Finance, vol. 26(2), pp. 184-199, 2002.

[11] E.I. Altman, "Financial Ratios, Discriminant Analysis and the Prediction of Corporate Bankruptcy," Journal of Finance, vol. 23(4), pp. 589-609, 1968.

[12] D. Hambrick and R. D'Aveni, "Large Corporate Failure as a Downward Spiral," Administrative Science Quarterly, vol. 33, pp. 1-23, 1988.

[13] K. Kraus and S. Haghani, "Krisenverlauf und Krisenbewältigung - der Aktuelle Stand," Die Unternehmenskrise als Chance, Berlin: Springer Verlag, pp. 13-37, 2004.

[14] A. Purnanandam, "Financial Distress and Corporate Risk Management: Theory \& Evidence," Working Paper, Ross School of Business, University of Michigan, 2005.

[15] T. Teubner, F. Hawlitschek, and D. Dann, "Price Determinants on Airbnb: How Reputation Pays Off in the Sharing Economy," Journal of Self-Governance and Management Economics, vol. 5(4), pp. 53-80, 2017.

[16] S. Scherrer, "From Warning to Crisis: A Turnaround Primer," Management Review, vol. 77(9), pp. 30-36, 1988.

[17] R. Whitaker, "The Early Stages of Financial Distress," Journal of Economics and Finance, vol. 23(2), pp. 123-133, 1999.

[18] P. Kelly, "Recognizing the North American Heartland: A More Suitable Fit for Mackinder's Thesis," Geopolitics, History, and International Relations, vol. 9(1), pp. 215-240, 2017.

[19] G. H. Popescu, M. Comănescu, and C. Manole, "Mobile Knowledge Work, Information Routines, and Digital Technologies," Psychosociological Issues in Human Resource Management, vol. 5(2), pp. 187-192, 2017. 